\title{
Methane production, digestion, ruminal fermentation, nitrogen balance, and milk production of cows fed corn silage- or barley silage-based diets
}

\author{
C. Benchaar, ${ }^{\star 1}$ F. Hassanat, ${ }^{\star}$ R. Gervais, $†$ P. Y. Chouinard,† H. V. Petit, ${ }^{\star}$ and D. I. Massé ${ }^{\star}$ \\ ${ }^{*}$ Dairy and Swine Research and Development Centre, Agriculture and Agri-Food Canada, Sherbrooke, Quebec, Canada J1M 0C8 \\ †Département des Sciences Animales, Université Laval, Quebec, Quebec, Canada G1V 0A6
}

\begin{abstract}
This study evaluated the effects of replacing barley silage (BS) with corn silage (CS) in dairy cow diets on enteric $\mathrm{CH}_{4}$ emissions, ruminal fermentation characteristics, digestion, milk production, and $\mathrm{N}$ balance. Nine ruminally cannulated lactating cows were used in a replicated $3 \times 3$ Latin square design $(32-\mathrm{d}$ period) and fed (ad libitum) a total mixed ration (TMR; forage:concentrate ratio 60:40; dry matter basis) with the forage portion consisting of either barley silage ( $0 \%$ CS; 0\% CS and 54.4\% BS in the TMR), a 50:50 mixture of both silages (27\% CS; $27.2 \%$ CS and $27.2 \%$ BS in the TMR), or corn silage ( $54 \%$ CS; $0 \%$ BS and $54.4 \%$ CS in the TMR). Increasing the CS proportion (i.e., at the expense of BS) also involved increasing the proportion of corn grain (at the expense of barley grain). Intake and digestibility of dry matter and milk production increased linearly as the proportion of CS increased in the diet. Increasing dietary CS proportion decreased linearly the acetate molar proportion and increased linearly that of propionate. Daily $\mathrm{CH}_{4}$ emissions tended to respond quadratically to increasing proportions of $\mathrm{CS}$ in the diet $(487,540$, and $523 \mathrm{~g} / \mathrm{d}$ for 0,27 , and $54 \%$ CS, respectively). Methane production adjusted for dry matter or gross energy intake declined as the amount of CS increased in the diet; this effect was more pronounced when cows were fed the $54 \%$ CS diet than the $27 \%$ CS diet. Increasing the CS proportion in the diet improved $\mathrm{N}$ utilization, as reflected by decreases in ruminal ammonia concentration and urinary $\mathrm{N}$ excretion and higher use of dietary $\mathrm{N}$ for milk protein secretion. Total replacement of BS with CS in dairy cow diets offers a strategy to decrease $\mathrm{CH}_{4}$ energy losses and control $\mathrm{N}$ losses without negatively affecting milk performance.
\end{abstract}

Key words: enteric methane, corn silage, barley silage, dairy cow

\section{INTRODUCTION}

In 2011, agricultural emissions in Canada were $54 \mathrm{Mt}$ of $\mathrm{CO}_{2}$ eq, representing $8 \%$ of total national greenhouse gases (GHG) emissions. Emissions from livestock accounted for $60 \%$ of agricultural emissions and, of that, $\mathrm{CH}_{4}$ from enteric fermentation accounted for $55 \%$ of direct livestock emissions, with $20 \%$ associated with $\mathrm{CH}_{4}$ from manure management (Environment Canada, 2013). Of the total gross energy consumed by the dairy cow, 4 to $7 \%$ is lost as $\mathrm{CH}_{4}$ (Kebreab et al., 2008). Thus, reducing enteric $\mathrm{CH}_{4}$ emissions is beneficial environmentally (i.e., $\mathrm{CH}_{4}$ is a potent $\mathrm{GHG}$ ), nutritionally (i.e., reducing energy losses), and economically (i.e., improved feed efficiency and increasing milk production).

It is well documented that feeding high-starch diets to ruminants decreases ruminal $\mathrm{pH}$, which favors propionate production at the expense of acetate (Bannink et al., 2008; Beauchemin et al., 2009). Consequently, the availability of hydrogen is lowered, which can inhibit the growth or the activity of rumen methanogens (Van Kessel and Russell, 1996). Rumen protozoa are also often decreased in ruminants fed high-starch diets, which also reduces the transfer of hydrogen from protozoa to methanogens (Wolin and Miller, 1988; Hegarty, 1999).

Corn silage (CS) and barley silage (BS) are the main forage components of dairy cow diets in eastern and western Canada, respectively. Because CS contains more starch than BS (Beauchemin and McGinn, 2005; Addah et al., 2011), increasing CS proportion in the diet can make the ruminal environment less favorable to methanogens. Therefore, lower $\mathrm{CH}_{4}$ energy losses are expected in cows fed CS-based diets as compared with cows fed BS-based diets. The objective of this study was to determine the effects of feeding CS- versus BS-based diets on $\mathrm{CH}_{4}$ production, digestion, ruminal fermentation parameters (including protozoa populations), N balance, milk production, and milk composition.

\section{MATERIALS AND METHODS}

Received June 11, 2013.

Accepted November 2, 2013.

${ }^{1}$ Corresponding author: chaouki.benchaar@agr.gc.ca
This study was conducted at the Dairy and Swine Research and Development Centre (Sherbrooke, Cana- 
Table 1. Chemical composition of barley silage and corn silage

\begin{tabular}{lcc}
\hline & \multicolumn{2}{c}{ Experimental silage } \\
\cline { 2 - 3 } Item & Barley silage & Corn silage \\
\hline Chemical composition & & \\
DM (\%) & 31.8 & 31.3 \\
OM & 93.9 & 96.9 \\
CP & 9.04 & 7.95 \\
NDF & 52.3 & 36.7 \\
ADF & 34.9 & 23.4 \\
ADL & 5.96 & 2.23 \\
Starch & 13.9 & 32.2 \\
Ether extract & 3.33 & 4.04 \\
Gross energy (Mcal/kg of DM) & 4.49 & 4.64 \\
Ensiling characteristics & & \\
pH & 4.31 & 4.08 \\
Lactic acid & 10.77 & 9.96 \\
Acetic acid & 0.78 & 1.16 \\
Propionic acid & $\mathrm{ND}$ & $\mathrm{ND}$ \\
Butyric acid & $\mathrm{ND}$ & $\mathrm{ND}$ \\
Ammonia & 0.135 \\
Ethanol & 0.25 & 0.075 \\
Water-soluble carbohydrates & 3.59 & 0.48 \\
\hline
\end{tabular}

${ }^{1} \mathrm{ND}=$ not detected.

da). Animal procedures were conducted under the approval of the Institutional Animal Care Committee of the Dairy and Swine Research and Development Center (Sherbrooke, Canada) and were in accordance with the guidelines of the Canadian Council on Animal Care (Ottawa, Canada; CCAC, 1993).

\section{Cows, Experimental Design, and Diets}

Nine multiparous lactating Holstein cows fitted with rumen cannulas $(10 \mathrm{~cm}$, Bar Diamond Inc., Parma, ID) were used in a replicated $3 \times 3$ Latin square design (32-d period). The cows averaged (mean \pm SD) $114 \pm$ 33 DIM at the start of the experiment with an average $\mathrm{BW}$ of $707 \pm 49 \mathrm{~kg}$ and $47 \pm 2.6 \mathrm{~kg} / \mathrm{d}$ of milk. The dietary treatments were (1) $0 \% \mathrm{CS}$ and $54.4 \%$ BS in the TMR (0\% CS), (2) $27.2 \% \mathrm{CS}$ and $27.2 \%$ BS in the TMR $(\mathbf{2 7 \%} \mathbf{C S})$, and (3) $54.4 \% \mathrm{CS}$ and $0 \%$ BS in the TMR $(\mathbf{5 4 \%}$ CS). The chemical composition and the ensiling characteristics of the 2 silages are presented in Table 1. The forage:concentrate ratio of the TMR was 60:40 on a DM basis. Increasing the proportion of CS in the diet (i.e., at the expense of BS) was achieved by decreasing the proportions of barley grain, soybean meal, and inert fat and increasing proportions of corn grain, corn gluten feed, soybean hulls, and urea (Table 2 ). Each diet was provided for ad libitum intake (5\% orts on an as-fed basis) and cows were housed in individual tiestalls and had free access to water during the experiment.

After 2 wk of adaptation to experimental diets, feed intake, in sacco ruminal degradability, rumen fermenta- tion characteristics (including protozoa enumeration), apparent total-tract digestibility, $\mathrm{N}$ balance, milk performance (production and composition), and $\mathrm{CH}_{4}$ production were measured. Only 2 air flow-controlled chambers were available for measuring $\mathrm{CH}_{4}$ emissions in this study, which limited the number of animals that could be examined at the same time to 2 (i.e., 1 cow/ chamber). Consequently, $\mathrm{CH}_{4}$ determination and all measurements had to be staggered by $4 \mathrm{~d}$ within the 18-d sampling and data collection period to facilitate measurements. Cows were weighed at the beginning and the end of each experimental period on 2 consecutive days before the AM feeding and after the AM milking.

\section{Intake, Apparent Total-Tract Digestibility, and $N$ Balance}

Apparent total-tract digestibility and $\mathrm{N}$ outputs were measured over 6 consecutive days as described in Hassanat et al. (2013). Diets were offered in equal amounts twice daily (0900 and $1930 \mathrm{~h}$ ). Feed consumption was recorded daily by weighing feeds offered to and refused by the cows. Samples of the TMR, feed ingredients, and orts were collected daily and stored at $-20^{\circ} \mathrm{C}$. Samples were composited by cow within period, freeze-dried, ground to pass a 1-mm screen using a Wiley mill (standard model 4; Arthur M. Thomas, Philadelphia, PA), and analyzed for DM, OM, total N, NDF, ADF, starch, ether extract (EE), and gross energy (GE). Samples of BS and CS were also analyzed for ADL, lactic acid, VFA, ethanol, ammonia N, and water-soluble carbohydrates. 
Table 2. Ingredient and chemical composition of the experimental diets

\begin{tabular}{|c|c|c|c|}
\hline \multirow[b]{2}{*}{ Item } & \multicolumn{3}{|c|}{ Treatment } \\
\hline & $0 \% \mathrm{CS}^{1}$ & $27 \% \mathrm{CS}$ & $54 \% \mathrm{CS}$ \\
\hline \multicolumn{4}{|l|}{ Ingredient ( $\%$ of $\mathrm{DM})$} \\
\hline Barley silage & 54.4 & 27.2 & - \\
\hline Corn silage & - & 27.2 & 54.4 \\
\hline Barley grain, rolled & 21.3 & 10.6 & - \\
\hline Corn grain, ground & - & 5.2 & 10.5 \\
\hline Corn gluten feed & - & 5.7 & 11.3 \\
\hline Soybean meal & 14.8 & 13.0 & 11.1 \\
\hline Timothy hay & 5.5 & 5.5 & 5.5 \\
\hline Soybean hulls & - & 2.3 & 4.6 \\
\hline Rumen-inert fat ${ }^{2}$ & 1.9 & 0.9 & - \\
\hline Urea & - & 0.2 & 0.4 \\
\hline Mineral and vitamin supplement ${ }^{3}$ & 1.8 & 1.4 & 1.5 \\
\hline Calcium carbonate & - & 0.4 & 0.6 \\
\hline Dicalcium phosphate & 0.3 & 0.3 & - \\
\hline \multicolumn{4}{|c|}{ Chemical composition (\% of DM, unless otherwise noted) } \\
\hline OM & 92.9 & 93.6 & 94.5 \\
\hline $\mathrm{CP}$ & 16.7 & 16.1 & 15.9 \\
\hline $\mathrm{NDF}$ & 37.8 & 35.4 & 32.4 \\
\hline $\mathrm{ADF}$ & 24.4 & 22.1 & 18.6 \\
\hline Starch & 16.6 & 20.6 & 25.6 \\
\hline Ether extract & 6.26 & 5.82 & 5.59 \\
\hline $\mathrm{NFC}^{4}$ & 32.1 & 36.3 & 40.6 \\
\hline Gross energy (Mcal/kg of DM) & 4.51 & 4.48 & 4.49 \\
\hline \multicolumn{4}{|c|}{${ }^{1} \mathrm{CS}=$ corn silage. } \\
\hline \multicolumn{4}{|c|}{${ }^{2}$ Energy Booster 100 (Milk Specialties Global Animal Nutrition, Carpentersville, IL). } \\
\hline \multicolumn{4}{|c|}{$\begin{array}{l}{ }^{3} \mathrm{Contained} 12.48 \% \mathrm{Ca}, 6.80 \% \mathrm{P}, 6.81 \% \mathrm{~S}, 7.72 \% \mathrm{Na}, 1.97 \% \mathrm{~K}, 96 \mathrm{mg} / \mathrm{kg} \text { of I, } 2,877 \mathrm{mg} / \mathrm{kg} \text { of Fe, } 620 \mathrm{mg} / \mathrm{kg} \\
\text { of } \mathrm{Cu}, 2,520 \mathrm{mg} / \mathrm{kg} \text { of } \mathrm{Mn}, 3,777 \mathrm{mg} / \mathrm{kg} \text { of } \mathrm{Zn}, 83 \mathrm{mg} / \mathrm{kg} \text { of } \mathrm{Co}, 628,000 \mathrm{IU} / \mathrm{kg} \text { of vitamin A, } 81,000 \mathrm{IU} / \mathrm{kg} \text { of } \\
\text { vitamin D, } 3,739 \mathrm{IU} / \mathrm{kg} \text { of vitamin E, and } 27.8 \mathrm{mg} / \mathrm{kg} \text { of Se. } \\
{ }^{4} \mathrm{NFC}=\mathrm{OM}-(\mathrm{CP}+\mathrm{NDF}+\text { ether extract }) .\end{array}$} \\
\hline
\end{tabular}

Total collection of feces and urine was performed as described by Hassanat et al. (2013) by fitting cows with harnesses and tubes allowing the collection of feces and urine separately. Feces were analyzed for DM, OM, total N, NDF, ADF, starch, EE, and GE concentrations. Urine was analyzed for total $\mathrm{N}$ content. Retained $\mathrm{N}$ was calculated by subtracting $\mathrm{N}$ in feces, urine, and milk from $\mathrm{N}$ intake, whereas productive $\mathrm{N}$ was calculated as the sum of $\mathrm{N}$ retained in the body and $\mathrm{N}$ secreted in milk.

\section{In Sacco Ruminal Degradability}

Ruminal degradability of BS and CS was determined using a nylon bag procedure as described in Hassanat et al. (2013). Silages were freeze-dried, ground to pass a 2-mm screen using a Wiley mill, and 5-g samples (DM) were weighed in triplicate in polyester bags $(17 \times 9$ $\mathrm{cm} ; 53 \mu \mathrm{m}$ pore size) made of monofilament PeCAP Polyester (Sefar Nitex, Sefar AG, Heiden, Switzerland). Bags were incubated in the ventral sac of the rumen for $2,4,8,16,24,48,72$, and $96 \mathrm{~h}$. Bags used for time 0 disappearance were soaked in water at $37^{\circ} \mathrm{C}$ for $5 \mathrm{~min}$ and then treated similar to the other bags.
Kinetics of ruminal degradation of OM of BS and CS were calculated using a nonlinear model (McDonald, 1981). The NLIN procedure of SAS (SAS Institute Inc., Cary, NC) was used to fit the model

$$
\begin{gathered}
P=a+b\left[1-\mathrm{e}^{-c(t-L)}\right] \text { for } t>L ; \\
P=a \text { for } t \leq L ;
\end{gathered}
$$

where $P=$ percentage of $\mathrm{OM}$ disappearance from the nylon bag at time $t ; a=$ soluble and rapidly degradable fraction (\%); $b=$ slowly degradable fraction (\%); $c=$ fractional rate of disappearance of the fraction $b$ (per hour); $L=$ lag time (h); and $t=$ time of incubation (h). The model was fitted using $(a+b) \leq 100, b \geq 0, c \geq$ 0 , and $L \geq 0$ constraints.

The effective ruminal degradability (ERD) of OM was calculated using

$$
\mathrm{ERD}=a+\left[b c /\left(c+k_{\mathrm{p}}\right)\right] \times \mathrm{e}^{\left(-k_{\mathrm{p}} L\right)}
$$

where $k_{\mathrm{p}}$ is the ruminal fractional passage rate, calculated at $0.05 / \mathrm{h}$ from the equations suggested by the NRC (2001) for wet forages. 


\section{Ruminal Fermentation Characteristics and Protozoa Enumeration}

Ruminal fluid was collected from cows on 2 successive days before $(0 \mathrm{~h})$ and at $1,2,4,6$, and $8 \mathrm{~h}$ after the AM feeding. A total of $250 \mathrm{~mL}$ was collected from the anterior dorsal, anterior ventral, medium ventral, posterior dorsal, and posterior ventral locations within the rumen using a $50-\mathrm{mL}$ syringe screwed to a stainless tube ending with a probe covered by a fine metal mesh (RT Rumen Fluid Collection Tube, Bar Diamond Inc.). Ruminal fluid was acidified to a $\mathrm{pH}$ of 2 with $50 \%$ sulfuric acid and subsamples $(15 \mathrm{~mL})$ were frozen at $-20^{\circ} \mathrm{C}$ for later determination of VFA and $\mathrm{NH}_{3}$ concentrations.

Ruminal pH was measured continuously for $48 \mathrm{~h}$ using Kahne Bolus system (KB1000, Kahne Limited, Auckland, New Zealand) as described in Hassanat et al. (2013). The $\mathrm{pH}$ data were summarized as mean $\mathrm{pH}$, minimum $\mathrm{pH}$, maximum $\mathrm{pH}$, time spent below $\mathrm{pH}$ 6.0, time spent below $\mathrm{pH} 5.6$, time spent below $\mathrm{pH} 5.2$, area (time $\times \mathrm{pH}$ ) when $5.6<\mathrm{pH}<6.0$, area when $5.2<\mathrm{pH}$ $<5.6$, and area when $\mathrm{pH}<5.2$ over $24 \mathrm{~h}$ (Plaizier et al., 2001; Keunen et al., 2002; Khafipour et al., 2009).

Protozoa were counted from ruminal content collected before $(0 \mathrm{~h})$ and $4 \mathrm{~h}$ after the AM feeding. Ruminal content (approximately $1 \mathrm{~L}$ ) was strained through 4 layers of cheesecloth and a 5 -mL portion of the strained ruminal fluid was preserved using $5 \mathrm{~mL}$ of methyl green formalin-saline solution for protozoa enumeration (Ogimoto and Imai, 1981). Protozoa samples were stored at room temperature in darkness until counting. Protozoa were microscopically enumerated using a counting chamber (Neubauer Improved Bright-Line counting cell, $0.1 \mathrm{~mm}$ depth; Hausser Scientific, Horshamm, PA) and genera were identified as outlined by Dehority (1993).

\section{Milk Production and Milk Composition}

Cows were milked in their stalls twice daily, at 0700 and $1900 \mathrm{~h}$, and milk production was recorded at each milking. During digestibility measurements, milk samples were collected from each cow at each milking, stored at $4^{\circ} \mathrm{C}$ with a preservative (2-bromo-2-nitropropan-1,3-diol), and then sent to a commercial laboratory (Valacta Dairy Production Center of Expertise QuebecAtlantic, Ste-Anne-de-Bellevue, Canada) for analyses of fat, protein, lactose, MUN, and SCC.

\section{Enteric Methane Production}

Enteric methane emissions were determined as described in Hassanat et al. (2013) using 2 air flow- controlled chambers for measurement of $\mathrm{CH}_{4}$ production. The chambers measured $4.09 \times 2.95 \times 2.84 \mathrm{~m}$ (length $\times$ width $\times$ height). When chambers doors were closed, air entered the chamber through a ventilation duct and exited through an exhaust. Air temperature within the chamber was maintained at $18 \pm 1^{\circ} \mathrm{C}$. Air flow into and out of the chamber was measured using Inline Mass Flowmeters (FT2, FOX Thermal Instruments Inc., Marina, CA) and maintained at $180 \pm 10$ $\mathrm{m}^{3} / \mathrm{h}$. Methane concentration was continuously measured at the air entrance and exhaust ducts using $\mathrm{CH}_{4}$ analyzers (MGA3000, ADC Gas Analysis Ltd., Hoddesdon, Herts, UK). The amount of $\mathrm{CH}_{4}$ (entering and leaving the chamber) was calculated by multiplying the concentration of $\mathrm{CH}_{4}$ by the airflow (at entrance and at exhaust). The difference between the incoming and outgoing mass of $\mathrm{CH}_{4}$ corresponded to the amount of enteric $\mathrm{CH}_{4}$ emitted in each chamber by the animal. Methane was recorded every minute over a period of 3 consecutive days and fluxes were averaged to derive 24-h $\mathrm{CH}_{4}$ emissions. Cows were preconditioned to the environmental chambers before the beginning of the experiment. Cows entered the chambers $18 \mathrm{~h}$ before starting $\mathrm{CH}_{4}$ measurements. Cows in the chambers had free access to water and were fed twice daily for ad libitum intake (5\% orts on an as-fed basis). Offered feed and orts were weighed daily to determine feed consumption. Samples of feed offered and orts were collected, pooled, and kept frozen for later determination of DM and GE concentrations.

\section{Chemical Analyses}

Dry matter content was determined by drying samples in a vacuum oven at $100^{\circ} \mathrm{C}$ overnight (AOAC, 1990; method 934.01). Ash content was determined by incineration at $550^{\circ} \mathrm{C}$ overnight in a muffle furnace (AOAC, 1990; method 942.05) and the OM content was calculated as the difference between 100 and the percentage of ash. Crude protein $(\mathrm{N} \times 6.25)$ was determined using the macro-Kjeldahl procedure (AOAC, 1990; method 990.03). The concentration of NDF was determined as described by Van Soest et al. (1991) without the use of sodium sulfite and with the inclusion of heat-stable $\alpha$-amylase. The ADF and ADL concentrations were determined according to AOAC (1990; method 973.18). The NDF and ADF procedures were adapted for use in an Ankom200 Fiber Analyzer (Ankom Technology Corp., Fairport, NY). The concentration of starch was determined colorimetrically according to the procedure of Hall et al. (2001). Ether extract was determined using the Soxtec 2047 Soxcap in combination with Soxtec extraction systems (Foss, Eden Prairie, MN) according to AOAC (1990; method 920.39). Gross energy 
was determined using an oxygen bomb calorimeter (model 6200, Parr Instrument Company, Moline, IL). The concentration of $\mathrm{N}$ in acidified urine samples was determined by micro-Kjeldahl analysis (AOAC, 1990). Water-soluble silage extracts were analyzed for watersoluble carbohydrates (Dubois et al., 1956), lactic acid (Taylor, 1996), and ethanol (GLC; model 6850, Agilent Technologies, Mississauga, Canada).

Analysis of VFA was performed using a gas chromatograph equipped with a flame ionization detector and auto-injector (7683 series; Agilent Technologies) and fitted with a DB-FFAP column $(30 \mathrm{~m} \times 0.250$ $\mathrm{mm}, 0.25 \mu \mathrm{m}$; Agilent Technologies). The gas flow rate in the column was fixed at $1 \mathrm{~mL} / \mathrm{min}$ and the temperature program was as an initial temperature of $80^{\circ} \mathrm{C}$ for $0.5 \mathrm{~min}$, a temperature increase at a rate of $25^{\circ} \mathrm{C} / \mathrm{min}$ to $180^{\circ} \mathrm{C}$, and stabilization at $220^{\circ} \mathrm{C}$ for $2 \mathrm{~min}$. The total run time was $7.83 \mathrm{~min}$. The injector and detector temperature was maintained at $250^{\circ} \mathrm{C}$, whereas the gas flow rates at the detector were 40, 450, and $25 \mathrm{~mL} /$ min for $\mathrm{H}_{2}$, air, and $\mathrm{N}_{2}$, respectively. Ammonia $\mathrm{N}$ concentration was determined as in Weatherburn (1967). Protein, fat, lactose, MUN, and SCC in milk samples were analyzed by infrared spectroscopy (MilkoScan FT 6000; Foss Electric, Hillerød, Denmark). Milk composition was corrected for differences in milk yield between $\mathrm{AM}$ and PM milkings.

\section{Statistical Analyses}

Data were analyzed using the MIXED procedure of SAS (SAS Institute Inc., Cary, NC). The statistical model included treatment and period as fixed effects and square and cow within square as random effects. Ruminal fermentation characteristics $\left(\mathrm{pH}, \mathrm{VFA}, \mathrm{NH}_{3}\right.$, protozoa) data were analyzed as repeated measures using the same model with the addition of the fixed effects of day, sampling time (i.e., hour), and all interactions. The $\mathrm{CH}_{4}$ data were also analyzed as repeated measures with the inclusion of the fixed effects of day and day $x$ treatment interaction. The fixed effect of the chamber was initially included in the model but was removed because it was not significant. The first-order autoregressive was used as the covariance structure and cow within treatment $\times$ period as subject for the repeated measures. In sacco ruminal degradability data were analyzed as a replicated $3 \times 3$ Latin square design and the model included the fixed effects of treatment and period as well as the random effect of square and cows within square. Orthogonal polynomial contrasts (linear, quadratic) were used to examine treatment effect on response variables. Significant effect of treatment on LSM was declared when $P \leq 0.05$, whereas tendencies were declared when $0.05<\bar{P} \leq 0.10$.

\section{RESULTS}

\section{Silage and Diet Composition}

Chemical composition and fermentation characteristics of CS and BS are presented in Table 1. As typically practiced in silage making for these 2 forages, the plants were harvested at a stage at which they contain a substantial concentration of starch (two-thirds milkline for CS and soft dough for BS). Barley silage contained 1 percentage unit more $\mathrm{CP}$ and 16 percentage units more NDF than CS, but 18 percentage units less starch. Proportion of lignin in NDF of BS was $11.4 \%$, whereas this proportion was $6.1 \%$ in CS. The 2 silages were of good quality, as reflected by low $\mathrm{pH}$, high lactic acid concentration, very small concentration of $\mathrm{NH}_{3}$, and no detectable presence of butyric acid.

Increasing the proportion of CS at the expense of BS was achieved by increasing the proportions of corn grain (i.e., at the expense of barley grain), corn gluten feed, soybean hulls, and urea (Table 2). Soybean meal was the main source of protein in the 3 experimental treatments and its proportion slightly decreased as the proportion of CS increased in the diet. As the CS proportion in the diet increased, NDF and ADF concentrations declined, CP concentration dropped slightly, and the starch concentration increased (Table 2). The difference in the chemical composition of the 3 experimental diets is therefore a reflection of the differences between BS and CS.

\section{Nutrient Intake and Digestibility}

Dry matter intake $(\mathrm{kg} / \mathrm{d}$ or $\%$ of BW) increased linearly $(P<0.01)$ as the CS proportion increased in the diet, leading to concomitant linear increases in $\mathrm{OM}$, $\mathrm{CP}$, starch, and GE intakes (Table 3). Intake of NDF was numerically $(P=0.13)$ higher for cows fed the 27 and $54 \%$ CS diets as compared with cows fed the $0 \%$ CS diet, whereas a quadratic decrease $(P=0.05)$ in $\mathrm{ADF}$ intake was observed as the CS proportion increased in the diet $(5.25,5.37$, and $4.78 \mathrm{~kg} / \mathrm{d}$ for 0 , 27 , and $54 \% \mathrm{CS}$, respectively). Intake of EE remained unchanged by feeding cows increasing levels of CS in the diet.

Apparent total-tract digestibility of DM, OM, starch, $\mathrm{EE}$, and GE increased linearly $(P<0.01)$, whereas that of $\mathrm{CP}$ tended $(P=0.09)$ to decline linearly as the proportion of CS increased in the diet. Digestibility of NDF tended $(P=0.09)$ to increase linearly with increasing inclusion of $\mathrm{CS}$ in the diet, whereas $\mathrm{ADF}$ digestibility was not significantly affected by experimental treatments, although it increased numerically $(P=0.12)$ with increasing dietary CS proportion. 
Table 3. Intake and apparent total-tract digestibility of nutrients in lactating dairy cows fed increasing proportions of corn silage (CS) in the diet

\begin{tabular}{|c|c|c|c|c|c|c|}
\hline \multirow[b]{2}{*}{ Item } & \multicolumn{3}{|c|}{ Treatment $^{1}$} & \multirow[b]{2}{*}{ SEM } & \multicolumn{2}{|c|}{$P$-value } \\
\hline & $0 \% \mathrm{CS}$ & $27 \% \mathrm{CS}$ & $54 \% \mathrm{CS}$ & & Linear & Quadratic \\
\hline \multicolumn{7}{|c|}{$\begin{array}{l}\text { Intake } \\
(\mathrm{kg} / \mathrm{d} \text {, unless otherwise noted })\end{array}$} \\
\hline DM & 21.9 & 24.9 & 26.2 & 0.66 & $<0.01$ & 0.13 \\
\hline $\mathrm{DM}(\%$ of $\mathrm{BW})$ & 2.99 & 3.42 & 3.57 & 0.079 & $<0.01$ & 0.08 \\
\hline $\mathrm{OM}$ & 20.4 & 23.3 & 24.8 & 0.63 & $<0.01$ & 0.16 \\
\hline $\mathrm{CP}$ & 3.71 & 4.05 & 4.21 & 0.131 & $<0.01$ & 0.33 \\
\hline $\mathrm{NDF}$ & 8.14 & 8.61 & 8.40 & 0.217 & 0.32 & 0.13 \\
\hline $\mathrm{ADF}$ & 5.25 & 5.37 & 4.78 & 0.160 & 0.03 & 0.05 \\
\hline Starch & 3.71 & 5.19 & 6.78 & 0.192 & $<0.01$ & 0.76 \\
\hline Ether extract & 1.38 & 1.45 & 1.48 & 0.050 & 0.20 & 0.77 \\
\hline Gross energy (Mcal/d) & 98.9 & 111.5 & 117.5 & 3.01 & $<0.01$ & 0.17 \\
\hline \multicolumn{7}{|l|}{ Digestibility (\%) } \\
\hline DM & 63.2 & 65.8 & 69.3 & 0.62 & $<0.01$ & 0.44 \\
\hline $\mathrm{OM}$ & 64.4 & 67.2 & 70.7 & 0.67 & $<0.01$ & 0.58 \\
\hline $\mathrm{CP}$ & 70.0 & 68.7 & 68.5 & 0.75 & 0.09 & 0.45 \\
\hline $\mathrm{NDF}$ & 42.4 & 43.5 & 46.2 & 1.84 & 0.09 & 0.68 \\
\hline $\mathrm{ADF}$ & 41.5 & 43.5 & 46.2 & 2.01 & 0.12 & 0.90 \\
\hline Starch & 92.0 & 94.9 & 97.9 & 0.48 & $<0.01$ & 0.99 \\
\hline Ether extract & 63.2 & 66.0 & 69.0 & 1.63 & $<0.01$ & 0.97 \\
\hline Gross energy & 62.7 & 65.2 & 69.0 & 0.71 & $<0.01$ & 0.33 \\
\hline
\end{tabular}

${ }^{1}$ The diet (60:40 forage:concentrate ratio; DM basis) contained 0\% CS (54.4\% barley silage), $27.2 \%$ CS (27.2\% barley silage), or $54.4 \%$ CS (0\% barley silage) on a DM basis.

\section{In Sacco Ruminal Degradability}

Data of in sacco ruminal OM degradation parameters and ERD of CS and BS are presented in Table 4. The rapidly degradable fraction $(a)$ of $\mathrm{BS}$ tended $(P=0.07)$ to decrease linearly, whereas that of CS decreased linearly $(P=0.03)$ as the proportion of CS increased in the diet. The slowly degradable fraction $(b)$ of BS tended $(P=0.10)$ to increase, whereas that of CS remained unaffected by feeding cows increasing proportions of CS in the diet. For both silages, the lag time $(L)$ was not affected by the experimental treatment, whereas the fractional degradation rate $(c)$ declined linearly $(P \leq$ 0.04) as the proportion of CS increased in the diet. As a consequence of these changes in degradation kinetic parameters, the ERD of the 2 silages decreased linearly $(P \leq 0.03)$ with increasing inclusion of $\mathrm{CS}$ in the diet. Overall, the ERD of OM of CS was 11 percentage units higher than that of BS.

\section{Ruminal Fermentation Characteristics and Protozoa}

Because the interactions between day and treatment were not significant for any of the ruminal fermentation parameters, only averages of the 2-d measurements were reported. Continuous monitoring of ruminal $\mathrm{pH}$ revealed minor effects of the experimental treatments on ruminal $\mathrm{pH}$ parameters (Table 5). No treatment $\times$ sampling time interaction was observed for total VFA concentration or molar proportions of individual VFA.
Total VFA concentration averaged $96.2 \mathrm{~m} M$ and was not affected by treatment. Increasing the dietary proportion of CS caused a linear decline $(P<0.01)$ in acetate molar proportion and an increase $(P=0.02)$ in propionate proportion, resulting in a linear decrease in the acetate:propionate ratio. Molar proportion of butyrate increased numerically $(P=0.15)$, valerate proportion increased linearly $(P=0.05)$, but the proportion of branched-chain VFA (isobutyrate and isovalerate) declined linearly $(P=0.03)$ as the dietary proportion of CS increased. Increasing the concentration of CS in the diet caused a linear decline in ruminal $\mathrm{NH}_{3}$ concentration (Table 6 ). The treatment $\times$ sampling time interaction was significant for ruminal $\mathrm{NH}_{3}$ concentration, which was different among the experimental treatments except at $1 \mathrm{~h}$ postfeeding, where no effect of the increasing CS proportion in the diet was observed (Figure 1).

No treatment $\times$ sampling time interactions were observed for total protozoa, entodiniomorphs, or holotrichs counts (Table 6). As the proportion of CS increased in the diet, the total protozoa and entodiniomorphs numbers increased linearly $(P \leq 0.03)$, whereas a linear decline $(P<0.01)$ in the holotrichs population count was observed. Dasytricha population declined $(P<0.01)$, whereas Isotricha number increased $(P=0.01)$ with increasing CS proportion in the diet. Overall, for all diets, $98 \%$ of the protozoa were entodinomorphs. 
Table 4. In sacco OM degradation kinetic parameters and effective degradability of barley and corn silages in lactating dairy cows fed increasing proportions of corn silage (CS) in the diet

\begin{tabular}{|c|c|c|c|c|c|c|}
\hline \multirow[b]{2}{*}{ Item $^{1}$} & \multicolumn{3}{|c|}{ Treatment $^{2}$} & \multirow[b]{2}{*}{ SEM } & \multicolumn{2}{|c|}{$P$-value } \\
\hline & $0 \% \mathrm{CS}$ & $27 \% \mathrm{CS}$ & $54 \%$ CS & & Linear & Quadratic \\
\hline \multicolumn{7}{|l|}{ Barley silage } \\
\hline$a(\%)$ & 45.6 & 45.5 & 44.9 & 0.26 & 0.07 & 0.47 \\
\hline$b(\%)$ & 30.3 & 31.7 & 33.8 & 1.33 & 0.10 & 0.83 \\
\hline$c(/ \mathrm{h})$ & 0.033 & 0.028 & 0.020 & 0.0023 & $<0.01$ & 0.51 \\
\hline Lag time $(\mathrm{h})$ & 4.58 & 4.66 & 3.72 & 0.834 & 0.37 & 0.53 \\
\hline $\operatorname{ERD}(\%)$ & 55.1 & 54.4 & 53.1 & 0.54 & 0.01 & 0.59 \\
\hline \multicolumn{7}{|l|}{ Corn silage } \\
\hline$a(\%)$ & 56.8 & 56.5 & 56.5 & 0.106 & 0.03 & 0.30 \\
\hline$b(\%)$ & 32.0 & 34.5 & 33.0 & 1.37 & 0.62 & 0.28 \\
\hline$c(/ \mathrm{h})$ & 0.032 & 0.026 & 0.023 & 0.0029 & 0.04 & 0.62 \\
\hline Lag time (h) & 4.74 & 5.39 & 4.64 & 0.739 & 0.90 & 0.33 \\
\hline $\operatorname{ERD}(\%)$ & 66.6 & 65.3 & 64.5 & 0.76 & 0.03 & 0.69 \\
\hline
\end{tabular}

${ }^{1} a=$ soluble and rapidly degradable fraction; $b=$ slowly degradable fraction; $c=$ fractional rate of disappearance of the fraction $b$; ERD = effective ruminal degradability.

${ }^{2}$ The diet (60:40 forage:concentrate ratio; DM basis) contained $0 \%$ CS ( $54.4 \%$ barley silage), $27.2 \%$ CS $(27.2 \%$ barley silage), or $54.4 \%$ CS (0\% barley silage) on a DM basis.

\section{Milk Production and Milk Composition}

Increasing the proportion of CS in the diet caused linear increases $(P \leq 0.01)$ in yields of milk, FCM, and ECM (Table 7). A linear decline $(P<0.01)$ in milk fat and MUN concentrations and a linear increase $(P<$ $0.01)$ in the milk lactose concentration were observed when cows were fed an increasing proportion of CS in the diet. Milk protein content increased quadratically $(P=0.04)$ with increasing levels of CS in the diet (3.31, 3.46 , and $3.47 \%$ for 0,27 , and $54 \%$ CS, respectively). Milk fat yield was not affected by treatment, whereas yields of milk protein and lactose increased linearly $(P$ $<0.01)$ with increasing inclusion of CS in the diet. Feed efficiency, expressed as kilograms of milk produced per kilograms of DMI, remained unchanged by the experimental treatment. However, when expressed on an FCM or ECM yield basis, feed efficiency decreased linearly $(P<0.01)$ as the amount of CS increased in the diet.

\section{Enteric Methane Production}

No interactions were observed between day and treatment for $\mathrm{CH}_{4}$ measurements; therefore, only averages over the 3 -d measurements were reported (Table 8). A tendency $(P=0.07)$ for a quadratic response of daily $\mathrm{CH}_{4}$ output $(\mathrm{g} / \mathrm{d})$ to increasing levels of CS in the diet was observed (487, 540, and 523 for 0,27 , and $54 \%$ CS, respectively). When expressed on a DMI or GE intake basis, $\mathrm{CH}_{4}$ production declined quadratically $(0.05<P$ $\leq 0.07)$ as the proportion of CS increased in the diet. The effect of the treatment was quadratic $(P=0.05)$ when $\mathrm{CH}_{4}$ production was expressed as a percentage of the DE intake (10.5, 9.94, and $8.21 \%$ for 0,27 , and $54 \%$ CS, respectively). When $\mathrm{CH}_{4}$ was expressed per

Table 5. Ruminal pH parameters of lactating dairy cows fed increasing proportions of corn silage (CS) in the diet

\begin{tabular}{|c|c|c|c|c|c|c|}
\hline \multirow[b]{2}{*}{ Item } & \multicolumn{3}{|c|}{ Treatment $^{1}$} & \multirow[b]{2}{*}{ SEM } & \multicolumn{2}{|c|}{$P$-value } \\
\hline & $0 \% \mathrm{CS}$ & $27 \% \mathrm{CS}$ & $54 \% \mathrm{CS}$ & & Linear & Quadratic \\
\hline \multicolumn{7}{|l|}{$\mathrm{pH}$} \\
\hline Mean & 6.35 & 6.37 & 6.32 & 0.032 & 0.61 & 0.37 \\
\hline Minimum & 5.83 & 5.74 & 5.76 & 0.046 & 0.27 & 0.37 \\
\hline Maximum & 6.87 & 6.91 & 6.85 & 0.025 & 0.56 & 0.11 \\
\hline Time to $\mathrm{pH}<6.0$ (min) & 62.4 & 96.1 & 132.2 & 41.92 & 0.26 & 0.98 \\
\hline Time to $\mathrm{pH}<5.6(\mathrm{~min})$ & 0.7 & 6.3 & 1.0 & 2.00 & 0.92 & 0.04 \\
\hline Time to $\mathrm{pH}<5.2(\min )$ & 0.0 & 0.0 & 0.0 & - & - & - \\
\hline Area $5.6<\mathrm{pH}<6.0(\mathrm{pH} \times \min / \mathrm{d})$ & 5.44 & 8.01 & 11.67 & 3.822 & 0.27 & 0.91 \\
\hline Area $5.2<\mathrm{pH}<5.6(\mathrm{pH} \times \min / \mathrm{d})$ & 0.06 & 0.53 & 0.07 & 0.169 & 0.97 & 0.04 \\
\hline Area $\mathrm{pH}<5.2(\mathrm{pH} \times \min / \mathrm{d})$ & 0.00 & 0.00 & 0.00 & - & - & - \\
\hline
\end{tabular}

${ }^{1}$ The diet (60:40 forage:concentrate ratio; DM basis) contained 0\% CS (54.4\% barley silage), $27.2 \%$ CS (27.2\% barley silage), or $54.4 \%$ CS ( $0 \%$ barley silage) on a DM basis. 


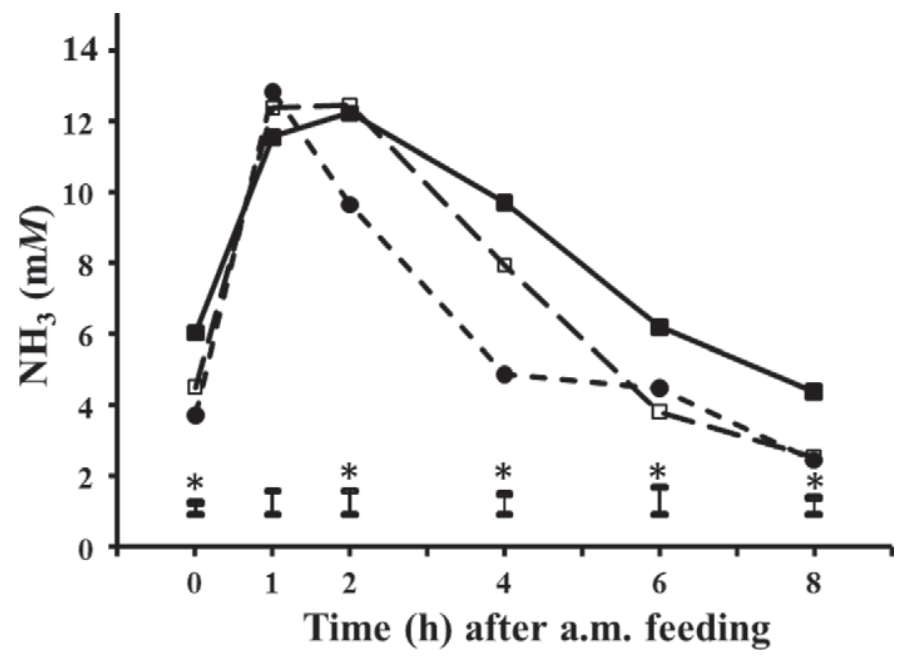

Figure 1. Ruminal $\mathrm{NH}_{3}$ concentration in lactating dairy cows fed increasing proportions of corn silage (CS) in the diet $(\mathbf{\square}=0 \% \mathrm{CS}, \square=$ $27 \% \mathrm{CS}, \bullet=54 \% \mathrm{CS}$ ). The diet (60:40 forage:concentrate ratio; DM basis) contained 0\% CS (54.4\% barley silage), $27.2 \%$ CS (27.2\% barley silage), or $54.4 \%$ CS (0\% barley silage) on a DM basis. Significant effect of treatment $(P<0.05)$ at specific sampling time is denoted by an asterisk (*).

kilogram of milk, FCM, or ECM produced, the numerically lowest $\mathrm{CH}_{4}$ production was observed in cows fed the $54 \%$ CS $\operatorname{diet}(0.12 \leq P \leq 0.16)$ as compared with cows fed the 0 and $27 \%$ CS diets (i.e., quadratic effects). Methane produced per kilogram of milk fat was numerically $(P=0.12)$ higher for cows fed the $27 \%$ CS diet as compared with cows fed the 0 and $54 \%$ CS diets. When expressed as kilograms of milk protein produced, $\mathrm{CH}_{4}$ production declined linearly $(P<0.01)$ with increasing inclusion of CS in the diet.

\section{N Balance}

Similar to the effect of treatment on DMI, daily N intake increased linearly $(P<0.01)$ as the proportion of CS increased in the diet (Table 9). Feeding cows increasing dietary proportions of CS caused a linear increase $(P<0.01)$ in the amount of $\mathrm{N}$ daily excreted in feces. Urinary $\mathrm{N}$ excretion $(\mathrm{g} / \mathrm{d})$ remained unaffected by increasing CS proportions in the diet, but it declined quadractically $(P=0.04)$ when expressed as a proportion of $\mathrm{N}$ intake. Daily total $\mathrm{N}$ excretion $(\mathrm{g} / \mathrm{d})$ tended $(P=0.06)$ to increase linearly with increasing inclusion of CS in the diet. However, when expressed as a proportion of daily $\mathrm{N}$ intake, it declined linearly $(P<0.01)$ when cows were fed increasing levels of CS in the diet. Efficiency of $\mathrm{N}$ utilization for milk production ( $\mathrm{N}$ in milk/N intake) tended to increase $(P=0.08)$, whereas retained $\mathrm{N}$ and productive $\mathrm{N}$ increased linearly with increasing proportion of CS in the diet.

\section{DISCUSSION}

In this study, increasing the proportion of CS in the diet was accompanied by an increase in DMI. This increase can be related to the decline in fiber content of the diet as the CS proportion increased in the diet, higher ruminal OM degradability of CS compared with BS (65.7 vs. $55.6 \%$ ), and improved apparent total-tract digestibility of diets containing more CS. Previous studies showed an inverse relationship between dietary fiber concentration and DMI (see review by Allen, 2000). Increasing fiber digestibility is generally associated with greater DMI (Allen, 2000), and this effect was also

Table 6. Total VFA concentration, VFA molar proportions, $\mathrm{NH}_{3}$ concentration, and protozoa numbers in ruminal fluid of lactating dairy cows fed increasing proportions of corn silage (CS) in the diet

\begin{tabular}{|c|c|c|c|c|c|c|}
\hline \multirow[b]{2}{*}{ Item } & \multicolumn{3}{|c|}{ Treatment $^{1}$} & \multirow[b]{2}{*}{ SEM } & \multicolumn{2}{|c|}{$P$-value } \\
\hline & $0 \% \mathrm{CS}$ & $27 \% \mathrm{CS}$ & $54 \% \mathrm{CS}$ & & Linear & Quadratic \\
\hline Total VFA $(\mathrm{m} M)$ & 93.1 & 97.7 & 97.8 & 3.78 & 0.23 & 0.51 \\
\hline \multicolumn{7}{|l|}{ VFA (mol/100 mol) } \\
\hline Acetate $(\mathrm{A})$ & 64.5 & 62.7 & 61.4 & 0.82 & $<0.01$ & 0.71 \\
\hline Propionate (P) & 20.9 & 21.8 & 23.6 & 1.02 & 0.02 & 0.68 \\
\hline Butyrate & 11.1 & 11.7 & 11.6 & 0.38 & 0.15 & 0.37 \\
\hline Valerate & 1.08 & 1.25 & 1.30 & 0.085 & 0.05 & 0.53 \\
\hline Branched-chain $\mathrm{VFA}^{2}$ & 2.46 & 2.52 & 2.10 & 0.130 & 0.03 & 0.10 \\
\hline A:P ratio & 3.14 & 2.92 & 2.74 & 0.118 & 0.01 & 0.89 \\
\hline $\mathrm{NH}_{3}(\mathrm{~m} M)$ & 8.34 & 7.27 & 6.32 & 0.433 & $<0.01$ & 0.88 \\
\hline \multicolumn{7}{|l|}{ Protozoa } \\
\hline Total $\left(\times 10^{5} / \mathrm{mL}\right)$ & 4.33 & 5.56 & 6.00 & 0.631 & 0.03 & 0.53 \\
\hline Entodiniomorphs $\left(\times 10^{5} / \mathrm{mL}\right)$ & 4.16 & 5.44 & 5.92 & 0.625 & 0.02 & 0.52 \\
\hline Holotrichs $^{3}\left(\times 10^{3} / \mathrm{mL}\right)$ & 16.5 & 11.6 & 7.82 & 2.152 & $<0.01$ & 0.79 \\
\hline Dasytrichs $\left(\times 10^{3} / \mathrm{mL}\right)$ & 13.10 & 6.53 & 0.60 & 1.991 & $<0.01$ & 0.86 \\
\hline Isotrichs $\left(\times 10^{3} / \mathrm{mL}\right)$ & 3.38 & 5.09 & 7.22 & 1.237 & 0.01 & 0.87 \\
\hline
\end{tabular}

${ }^{1}$ The diet (60:40 forage:concentrate ratio; DM basis) contained 0\% CS ( $54.4 \%$ barley silage), $27.2 \%$ CS (27.2\% barley silage), or $54.4 \%$ CS (0\% barley silage), on DM basis.

${ }^{2}$ Branched-chain VFA = isobutyrate + isovalerate.

${ }^{3}$ Holotrichs $=$ isotrichs + dasytrichs. 
Table 7. Milk production and milk composition of lactating dairy cows fed increasing proportions of corn silage (CS) in the diet

\begin{tabular}{|c|c|c|c|c|c|c|}
\hline Item & \multicolumn{3}{|c|}{ Treatment $^{1}$} & SEM & \multicolumn{2}{|c|}{$P$-value } \\
\hline \multicolumn{7}{|l|}{ Production $(\mathrm{kg} / \mathrm{d})$} \\
\hline $\mathrm{FCM}^{2}$ & 32.5 & 34.6 & 35.2 & 1.60 & 0.01 & 0.36 \\
\hline $\mathrm{ECM}^{3}$ & 35.1 & 37.9 & 38.9 & 1.52 & $<0.01$ & 0.29 \\
\hline \multicolumn{7}{|c|}{ Components (\%, unless otherwise noted) } \\
\hline $\mathrm{SCC}\left(\times 10^{3} / \mathrm{mL}\right)$ & 92 & 124 & 105 & 24.3 & 0.57 & 0.22 \\
\hline $\operatorname{MUN}(\mathrm{mg} / \mathrm{dL})$ & 15.8 & 14.0 & 12.7 & 0.61 & $<0.01$ & 0.53 \\
\hline \multicolumn{7}{|l|}{ Yield $(\mathrm{kg} / \mathrm{d})$} \\
\hline Fat & 1.32 & 1.37 & 1.36 & 0.091 & 0.39 & 0.37 \\
\hline Protein & 1.06 & 1.21 & 1.27 & 0.030 & $<0.01$ & 0.16 \\
\hline Lactose & 1.42 & 1.57 & 1.69 & 0.050 & $<0.01$ & 0.69 \\
\hline
\end{tabular}

${ }^{1}$ The diet (60:40 forage:concentrate ratio; DM basis) contained 0\% CS (54.4\% barley silage), $27.2 \%$ CS (27.2\% barley silage), or $54.4 \%$ CS (0\% barley silage) on a DM basis.

${ }^{2} 4 \%$ FCM $($ Tyrrell and Reid, 1965$)=0.4 \times$ milk yield $(\mathrm{kg} / \mathrm{d})+15 \times$ fat yield $(\mathrm{kg} / \mathrm{d})$.

${ }^{3} \mathrm{ECM}($ Tyrrell and Reid, 1965$)=0.327 \times$ milk yield $(\mathrm{kg} / \mathrm{d})+12.95 \times$ fat yield $(\mathrm{kg} / \mathrm{d})+7.2 \times$ protein yield $(\mathrm{kg} / \mathrm{d})$.

observed in the current study when cows were fed increasing proportions of CS in the diet. Beauchemin and McGinn (2005) also reported higher DMI when beef cattle (back-grounding diet; 70:30 forage:concentrate ratio) were fed a CS-based diet as compared with when they were fed a BS-based diet.

It is well documented that enteric $\mathrm{CH}_{4}$ emission is positively related to DMI (Benchaar et al., 2001; Reynolds et al., 2011). This proportional relationship between
$\mathrm{CH}_{4}$ production and DMI was observed in the current study, as cows fed the $0 \% \mathrm{CS}$ diet (i.e., $54.4 \% \mathrm{BS}$ in the TMR) consumed $22.0 \mathrm{~kg}$ of $\mathrm{DM} / \mathrm{d}$ and produced 487 $\mathrm{g}$ of $\mathrm{CH}_{4} / \mathrm{d}$, whereas those fed the $27 \% \mathrm{CS}$ diet (i.e., $27.2 \%$ CS and $27.2 \%$ BS in the TMR) consumed 24.9 $\mathrm{kg}$ of $\mathrm{DM} / \mathrm{d}$ and produced $540 \mathrm{~g}$ of $\mathrm{CH}_{4} / \mathrm{d}$. To the best of our knowledge, ours is the first study evaluating enteric $\mathrm{CH}_{4}$ production from dairy cows fed CS or BS. In one study on feedlot cattle, Beauchemin and McGinn

Table 8. Methane production of lactating dairy cows fed increasing proportions of corn silage (CS) in the diet

\begin{tabular}{|c|c|c|c|c|c|c|}
\hline \multirow[b]{2}{*}{ Item } & \multicolumn{3}{|c|}{ Treatment $^{1}$} & \multirow[b]{2}{*}{ SEM } & \multicolumn{2}{|c|}{$P$-value } \\
\hline & $0 \% \mathrm{CS}$ & $27 \%$ CS & $54 \% \mathrm{CS}$ & & Linear & Quadratic \\
\hline $\mathrm{DMI}^{2}(\mathrm{~kg} / \mathrm{d})$ & 22.0 & 24.9 & 27.2 & 0.77 & $<0.01$ & 0.57 \\
\hline $\mathrm{CH}_{4}$ & & & & & & \\
\hline $\mathrm{g} / \mathrm{d}$ & 487 & 540 & 523 & 17.2 & 0.11 & 0.07 \\
\hline $\mathrm{g} / \mathrm{kg}$ of DMI & 22.3 & 21.8 & 19.1 & 0.58 & $<0.01$ & 0.07 \\
\hline$\% \mathrm{GE}_{\text {intake }}^{3}$ & 6.60 & 6.49 & 5.67 & 0.174 & $<0.01$ & 0.06 \\
\hline$\%$ DE intake ${ }^{4}$ & 10.5 & 9.94 & 8.21 & 0.238 & $<0.01$ & 0.05 \\
\hline $\mathrm{g} / \mathrm{kg}$ of milk ${ }^{5}$ & 15.3 & 15.6 & 14.4 & 0.60 & 0.15 & 0.16 \\
\hline $\mathrm{g} / \mathrm{kg}$ of $\mathrm{FCM}^{5}$ & 15.2 & 15.8 & 15.0 & 0.65 & 0.68 & 0.12 \\
\hline $\mathrm{g} / \mathrm{kg}$ of $\mathrm{ECM}^{5}$ & 14.0 & 14.4 & 13.5 & 0.51 & 0.33 & 0.15 \\
\hline $\mathrm{g} / \mathrm{kg}$ of milk $\mathrm{fat}^{5}$ & 380 & 401 & 387 & 23.1 & 0.59 & 0.12 \\
\hline $\mathrm{g} / \mathrm{kg}$ of milk protein ${ }^{5}$ & 462 & 451 & 412 & 13.9 & 0.01 & 0.38 \\
\hline
\end{tabular}

${ }^{1}$ The diet (60:40 forage:concentrate ratio; DM basis) contained 0\% CS ( $54.4 \%$ barley silage), $27.2 \%$ CS (27.2\% barley silage), or $54.4 \%$ CS (0\% barley silage) on a DM basis.

${ }^{2}$ Determined for 3 consecutive days during which cows were in the chambers.

${ }^{3} \mathrm{GE}=$ gross energy.

${ }^{4} \mathrm{DE}=$ digestible energy (estimated from energy digestibility measured over the 6-d collection period).

${ }^{5}$ Yields of milk, FCM, ECM, milk fat, and milk protein measured for 6 consecutive days (i.e., performance measurements). 
Table 9. Nitrogen balance in lactating dairy cows fed increasing proportions of corn silage (CS) in the diet

\begin{tabular}{|c|c|c|c|c|c|c|}
\hline \multirow[b]{2}{*}{ Item } & \multicolumn{3}{|c|}{ Treatment $^{1}$} & \multirow[b]{2}{*}{ SEM } & \multicolumn{2}{|c|}{$P$-value } \\
\hline & $0 \% \mathrm{CS}$ & $27 \% \mathrm{CS}$ & $54 \% \mathrm{CS}$ & & Linear & Quadratic \\
\hline \multirow{2}{*}{\multicolumn{7}{|c|}{ Fecal N }} \\
\hline & & & & & & \\
\hline $\mathrm{g} / \mathrm{d}$ & 178 & 203 & 213 & 8.6 & $<0.01$ & 0.28 \\
\hline$\%$ of $\mathrm{N}$ intake & 30.2 & 31.3 & 31.5 & 0.79 & 0.16 & 0.55 \\
\hline \multicolumn{7}{|l|}{ Urinary N } \\
\hline $\mathrm{g} / \mathrm{d}$ & 228 & 222 & 224 & 8.2 & 0.73 & 0.66 \\
\hline$\%$ of $\mathrm{N}$ intake & 38.8 & 34.3 & 33.4 & 0.83 & $<0.01$ & 0.04 \\
\hline \multicolumn{7}{|c|}{ Total N excretion } \\
\hline $\mathrm{g} / \mathrm{d}$ & 406 & 426 & 437 & 14.2 & 0.06 & 0.75 \\
\hline$\%$ of $\mathrm{N}$ intake & 69.0 & 65.6 & 64.9 & 0.90 & $<0.01$ & 0.16 \\
\hline \multicolumn{7}{|l|}{ Milk N } \\
\hline $\mathrm{g} / \mathrm{d}$ & 166 & 189 & 200 & 5.02 & $<0.01$ & 0.18 \\
\hline$\%$ of $\mathrm{N}$ intake & 28.3 & 29.2 & 30.0 & 1.11 & 0.08 & 0.94 \\
\hline \multicolumn{7}{|l|}{ Retained N } \\
\hline $\mathrm{g} / \mathrm{d}$ & 18.4 & 33.9 & 36.7 & 7.64 & 0.02 & 0.30 \\
\hline$\%$ of $\mathrm{N}$ intake & 2.81 & 5.13 & 5.09 & 1.105 & 0.05 & 0.22 \\
\hline \multicolumn{7}{|l|}{ Productive $\mathrm{N}^{2}$} \\
\hline $\mathrm{g} / \mathrm{d}$ & 186 & 223 & 236 & 10.3 & $<0.01$ & 0.08 \\
\hline$\%$ of $\mathrm{N}$ intake & 31.0 & 34.4 & 35.1 & 0.90 & $<0.01$ & 0.16 \\
\hline
\end{tabular}

(2005) also observed higher $\mathrm{CH}_{4}$ emissions (g/d) when beef cattle were fed CS-based diets compared with BSbased diets. However, despite higher DMI for cows fed the $54 \%$ CS diet (i.e., $0 \%$ BS in the TMR) compared with cows fed the $0 \%$ CS diet (27.2 vs. $22.0 \mathrm{~kg} / \mathrm{d}$ ), daily $\mathrm{CH}_{4}$ emission was not affected. A quadratic decline was observed when $\mathrm{CH}_{4}$ production was adjusted for intake of DM, GE, or DE. Thus, in the current study, the effect on $\mathrm{CH}_{4}$ production of starch content of the diet was more pronounced when the starch level was increased from 16.6 (i.e., $0 \% \mathrm{CS}$ diet) to $25.6 \%$ (i.e., $54 \% \mathrm{CS}$ diet) than from 16.6 to $20.6 \%$ (i.e., $27 \%$ CS diet). This indicates that ruminal environment was less favorable to ruminal methanogenesis when cows were fed the $54 \%$ CS diet than the 27\% CS diet. Previous studies reported that increasing dietary starch concentration in beef cattle (Mc Geough et al., 2010b) or dairy cows (Hassanat et al., 2013) alters ruminal environment and attenuates enteric $\mathrm{CH}_{4}$ emissions.

Increasing starch supply via increasing CS proportion in the diet had no effect on ruminal $\mathrm{pH}$, which is somewhat unexpected because feeding high-starch diets to ruminants is usually associated with a decrease in ruminal pH. However, the lack of effects of experimental treatments on ruminal $\mathrm{pH}$ in the current study is consistent with the absence of a difference in total VFA concentration. Conversely, changes in VFA patterns observed in our study when cows were fed an increasing dietary proportion of CS are typical of those occurring when high-starch diets are fed to ruminants (i.e., a decline in acetate molar proportion and an increase in propionate molar proportion). In the same experiment, using the cDNA technique, we (Lettat and Benchaar, 2013) showed that this increase in propionate molar proportion when cows were fed more CS (i.e., at the expense of BS) was associated with an increase in Prevotella numbers. This bacterium is the dominant amylolytic bacterial group and an efficient hydrogen user for propionate production (Bekele et al., 2010; Purushe et al., 2010). In a previous study (Benchaar et al., 2007) with dairy cows, replacing an alfalfa silage-based $\operatorname{diet}(17.6 \%$ starch; $39.3 \% \mathrm{NDF})$ with a CS-based diet (25.0\% starch; $37.5 \%$ NDF) caused similar effects on ruminal fermentation environment (i.e., no change in ruminal $\mathrm{pH}$, but a decline in acetate:propionate ratio). This shift in ruminal VFA pattern may explain lower $\mathrm{CH}_{4}$ emissions in cows fed increasing levels of CS in the diet given the inverse relationship between propionate and $\mathrm{CH}_{4}$ formation in the rumen. The production of acetate releases hydrogen, whereas the production of propionate serves as a net hydrogen sink, which reduces hydrogen availability to methanogens for the reduction of $\mathrm{CO}_{2}$ to $\mathrm{CH}_{4}$ (Beauchemin et al., 2009; Martin et al., 2010).

The increase in propionate proportion observed in the current study can be related to an increase in starch dietary supply to the rumen as CS proportion in the diet increased $(3.71,5.19$, and $6.78 \mathrm{~kg} / \mathrm{d}$ for 0,27 , and $54 \%$ CS, respectively). The increased propionate production can also be attributed to the higher DMI and 
passage rates and a shift toward faster-growing bacterial species in the rumen. Previous studies (Oba and Allen, 2000a, b) reported faster passage rates and higher propionate proportion associated with increased DMI in dairy cows. The decline in acetate molar proportion as CS dietary proportion increased could be related to the negative effect of treatment (i.e., increased starch supply) on fiber degradation as reflected by changes in the ruminal degradability of BS and CS. A negative association exists between starch and fiber degradation in the rumen (Van Soest, 1994). Conversely, fiber apparent total-tract digestibility tended to increase linearly as the proportion of CS increased in the diet. This may be explained by the high fiber quality of diets formulated with CS compared with BS (i.e., lower lignification of $\mathrm{CS}$ ), and a possible increase in postruminal fiber digestion as CS dietary proportion increased.

Protozoa are important hydrogen producers that play a key role in the interspecies hydrogen transfer and $\mathrm{CH}_{4}$ production within the rumen microbial ecosystem (Morgavi et al., 2012). Protozoa produce hydrogen during nutrient fermentation in the rumen, which is then used by Archaea methanogens (present inside and on the surface of protozoa) for $\mathrm{CH}_{4}$ synthesis.

It is generally speculated that high-starch diets causes a decrease in protozoa numbers (Beauchemin et al., 2009; Martin et al., 2010). Indeed, in a previous study, we (Hassanat et al., 2013) observed a reduction in protozoa numbers when CS (i.e., higher starch content) replaced alfalfa silage (i.e., lower starch content) in dairy cow diets. Similarly, Hristov et al. (2001) also reported a reduction in the ruminal protozoa number in steers fed high-concentrate diets (95\% barley-based diets) as compared with steers fed medium-concentrate diets (62\% barley-based diets). In the current study, however, increasing the proportion of CS in the diet (i.e., increased starch supply) caused a linear increase in protozoa numbers. The increase in protozoa numbers in the current study is consistent with the numerical increase in butyrate molar proportion because protozoa are butyrate producers (Ivan et al., 2000; Brossard et al., 2004; Morgavi et al., 2012). The increase of total protozoa and entodiniomorphs numbers with increasing starch supply observed in the current study are in agreement with previous studies in steers (Goad et al., 1998), sheep (Ivan et al., 2000), and dairy cows (Monteils et al., 2012) fed high-starch diets. The decline in Dasytricha population with increasing CS proportion is consistent with the observation of Ueda et al. (2003) in cows fed high-concentrate versus high-forage diets. Discrepancies between studies on the effect (increase vs. decrease) of starch supplementation on ruminal protozoa number could be explained by the level of starch of the diet. Indeed, in the present study, dietary starch concentrations increased up to $25.6 \%$ for the highest inclusion level of CS (i.e., 54\% CS diet), and this starch level content did not negatively affect ruminal protozoa numbers. In contrast, in the study by Hassanat et al. (2013), starch concentration increased up to $30 \%$ and was associated with a decrease in protozoa numbers. Thus, starch may be detrimental to protozoa at a high level of supplementation. Dijkstra (1994) reported that responses of ruminal protozoa to increases in dietary starch content depend on the type of the diet. Increasing starch content decreased protozoal biomass on high-concentrate diets but increased protozoal biomass on high-forage diets. The diets used in the present study were $60 \%$ forage-based diets, therefore explaining the increase in protozoa numbers with increasing starch concentration in the diet. Finally, it is equally possible that the high protozoa numbers in cows fed increasing proportions of CS was due to the higher DMI observed in cows fed the 27 and 54\% CS diets as compared with cows fed the $0 \%$ CS diet, as reported in other previous studies (Djouvinov and Todorov 1994; Aoki et al., 2010; Benchaar et al., 2012).

In this study, production of milk, FCM, and ECM increased with increasing proportions of CS in the diet, which can be explained by the increase in DM and energy intakes as the amount of CS fed to cows increased in the diet. Parallel increases in DMI and milk yield are often observed when dairy cows are fed high-starch versus high-fiber diets (Aguerre et al., 2011; Benchaar et al., 2012; Hassanat et al., 2013).

Feeding cows more CS at the expense of BS decreased milk fat content, but milk fat yield remained unaffected by experimental treatment, suggesting a dilution effect due to higher milk yield when cows were fed increasing amounts of CS in the diet. In contrast, the effect of feeding an increasing CS proportion in the diet to cows on milk protein secretion (higher concentration and yield of milk protein) is a typical change occurring when high-starch diets are fed to dairy cows. This increase in milk protein content and yield may be explained by a greater supply of AA due to an increased feed $\mathrm{N}$ intake coupled with a better utilization of $\mathrm{N}$ by the animal, as reflected by decreases in ruminal ammonia concentration, molar proportion of branchedchain VFA and MUN, and improved N retention. The utilization of ammonia in the rumen is strongly affected by availability of fermentable carbohydrates (Russell et al., 1983). Hristov et al. (2005) indicated that increasing availability of fermentable carbohydrates (i.e., starch) can decrease ammonia production in the rumen (by reducing the deamination process or enhancing the capture of released AA by ruminal microbes) or increase microbial capture of released $\mathrm{NH}_{3}$ in the rumen. Higher milk protein secretion in cows fed high-starch diets has 
been related to a greater production of propionate and increased supply of AA (Jenkins and McGuire, 2006), which occurred in the current study as the proportion of CS increased in the diet. The extent of starch digestibility observed in this study is similar to what was reported for barley (Gozho and Mutsvangwa, 2008) and corn (Hassanat et al., 2013). Digestibility of starch increased as the proportion of CS in the diet increased. This may reflect an enhanced postruminal digestion of starch, as ruminal degradability of starch from corn is known to be lower than that of barley (Offner et al., 2003; Yahaghi et al., 2012). Increased intestinal starch digestibility may have potentially spared AA from glycogenic oxidation, and thus increased AA availability for milk protein synthesis.

As a consequence of these changes in milk performance, the amount of $\mathrm{CH}_{4}$ produced per kilogram of milk was numerically lower when cows were fed the $54 \%$ CS diet compared with cows fed the 0 and $27 \%$ CS diets. When expressed on a milk protein yield basis, $\mathrm{CH}_{4}$ emissions decreased as CS replaced BS in the diet. When expressed on milk fat yield basis, $\mathrm{CH}_{4}$ production was numerically higher $(5 \%)$ for cows fed the $27 \%$ CS diet as compared with cows fed the 0 and $54 \%$ CS diets. In agreement with our findings, Aguerre et al. (2011) reported a decline in grams of $\mathrm{CH}_{4}$ emitted per kilograms of milk or ECM produced as dietary starch concentration was increased at the expense of fiber content (high-concentrate vs. high-forage diets). Mc Geough et al. (2010a, b) also reported that the amount of $\mathrm{CH}_{4}$ emitted per kilogram of carcass gain of beef cattle decreased as starch concentrations increased in corn silage- or wheat silage-based diet.

The success of a given dietary $\mathrm{CH}_{4}$ mitigation strategy relies also on its effect on emissions of other GHG to ensure that the gain achieved via the reduction in enteric $\mathrm{CH}_{4}$ emission is not offset by higher emissions, such as $\mathrm{N}_{2} \mathrm{O}$. High $\mathrm{N}$ excretion in urine has the potential to increase $\mathrm{N}_{2} \mathrm{O}$ and $\mathrm{NH}_{3}$ emissions. In the current study, including more CS in the diet at the expense of $\mathrm{BS}$ was associated with a greater fecal $\mathrm{N}$ output, which is due to higher $\mathrm{N}$ intake when cows were fed increasing levels of CS in the diet. The difference in fecal $\mathrm{N}$ between treatments was less pronounced when fecal $\mathrm{N}$ excretion was expressed as a proportion of $\mathrm{N}$ intake. Unlike fecal $\mathrm{N}$, urinary $\mathrm{N}(\mathrm{g} / \mathrm{d})$ was not affected by treatment and declined when expressed as a percentage of $\mathrm{N}$ intake. The lower urinary $\mathrm{N}$ losses can be explained by an improved $\mathrm{N}$ utilization in the rumen (i.e., lower ruminal protein degradation or improved capture of ammonia by rumen microbes) as previously discussed. In agreement with our findings, urinary $\mathrm{N}$ losses were lower in dairy cows fed a TMR containing starch from corn compared with those fed TMR con- taining starch from barley (Gozho and Mutsvangwa, 2008; Whelan et al., 2012). Reducing urine N excretion can help decrease animal contributions to GHG emissions, as urinary $\mathrm{N}$ can easily and rapidly be degraded during manure handling and storage and contribute to GHG emissions (FAO, 2006).

\section{CONCLUSIONS}

Mitigation of enteric $\mathrm{CH}_{4}$ production could be achieved by increasing the CS proportion at the expense of BS in dairy cow diets. However, under the experimental conditions of the current study, an evident decline $(14 \%)$ in enteric $\mathrm{CH}_{4}$ energy loss was observed only when CS entirely replaced BS in the diet (0 vs. $54 \%$ CS diets). The $14 \%$ reduction in $\mathrm{CH}_{4}$ energy losses was associated with a lower acetate:propionate ratio with no negative effects on nutrient digestibility, including that of fiber. Increasing CS dietary proportion improved milk production and this effect was due to a stimulation of DMI. Urinary $\mathrm{N}$ losses decreased as the amount of CS included in the diet was increased at the expense of BS, reflecting an enhanced efficiency of $\mathrm{N}$ use by the animal and suggesting a low potential for $\mathrm{N}_{2} \mathrm{O}$ and ammonia emissions.

\section{ACKNOWLEDGMENTS}

The authors of this study gratefully acknowledge the assistance of L. Croteau and P. Warburton (technical support), F. Tremblay (methane measurements), S. Méthot (help with the statistical analyses), and the barn crew (care of the cows; all from the Dairy and Swine Research Centre, Agriculture and Agri-Food Canada, Sherbrooke, QC). The authors also express their thanks to Y. Leboeuf and M. Gingras (Université Laval, Quebec, Canada) for their technical support. This study was funded by a grant (Dairy Research Cluster) from the Dairy Farmers of Canada (Ottawa, Canada), Agriculture and Agri-Food Canada (Ottawa, Canada), and Canadian Dairy Commission (Ottawa, Canada).

\section{REFERENCES}

Addah, W., J. Baah, P. Groenewegen, E. K. Okine, and T. A. McAllister. 2011. Comparison of the fermentation characteristics, aerobic stability and nutritive value of barley and corn silages ensiled with or without a mixed bacterial inoculant. Can. J. Anim. Sci. 91:133-146.

Aguerre, M. J., M. A. Wattiaux, J. M. Powell, G. A. Broderick, and C. Arndt. 2011. Effect of forage-to-concentrate ratio in dairy cow diets on emission of methane, carbon dioxide, and ammonia, lactation performance, and manure excretion. J. Dairy Sci. 94:30813093.

Allen, M. S. 2000. Effects of diet on short-term regulation of feed intake by lactating dairy cattle. J. Dairy Sci. 83:1598-1624. 
AOAC. 1990. Official Methods of Analysis. 15th ed. AOAC, Arlington, VA.

Aoki, N., S. Furukawa, K. Sato, Y. Kurokawa, S. Kanda, Y. Takahashi, H. Mitsuzumi, and H. Itabashi. 2010. Supplementation of the diet of dairy cows with trehalose results in milk with low lipid peroxide and high antioxidant content. J. Dairy Sci. 93:4189-4195.

Bannink, A., J. France, S. Lopez, W. J. J. Gerrits, E. Kebreab, S. Tamminga, and J. Dijkstra. 2008. Modelling the implications of feeding strategy on rumen fermentation and functioning of the rumen wall. Anim. Feed Sci. Technol. 143:3-26.

Beauchemin, K. A., T. A. McAllister, and S. M. McGinn. 2009. Dietary mitigation of enteric methane from cattle. CAB Rev. Perspect. Agric. Vet. Sci. Nutr. Nat. Resour. 35:1-18.

Beauchemin, K. A., and S. M. McGinn. 2005. Methane emissions from feedlot cattle fed barley or corn diets. J. Anim. Sci. 83:653-661.

Bekele, A. Z., S. Koike, and Y. Kobayashi. 2010. Genetic diversity and diet specificity of ruminal Prevotella revealed by $16 \mathrm{~S}$ rRNA genebased analysis. FEMS Microbiol. Lett. 305:49-57.

Benchaar, C., A. Lettat, F. Hassanat, W. Z. Yang, R. J. Forster, H. V. Petit, and P. Y. Chouinard. 2012. Eugenol for dairy cows fed low or high concentrate diets: Effects on digestion, ruminal fermentation characteristics, rumen microbial populations and milk fatty acid profile. Anim. Feed Sci. Technol. 178:139-150.

Benchaar, C., H. V. Petit, R. Berthiaume, D. R. Ouellet, J. Chiquette, and P. Y. Chouinard. 2007. Effects of essential oils on digestion, ruminal fermentation, rumen microbial populations, milk production, and milk composition in dairy cows fed alfalfa silage or corn silage. J. Dairy Sci. 90:886-897.

Benchaar, C., C. Pomar, and J. Chiquette. 2001. Evaluation of dietary strategies to reduce methane production in ruminants: A modelling approach. Can. J. Anim. Sci. 81:563-574.

Brossard, L., C. Martin, F. Chaucheyras-Durand, and B. MichaletDoreau. 2004. Protozoa involved in butyric rather than lactic fermentative pattern during latent acidosis in sheep. Reprod. Nutr. Dev. 44:195-206.

CCAC. 1993. Guide to the Care and Use of Experimental Animals. Vol. 1. 2nd ed. Canadian Council on Animal Care, Ottawa, Canada.

Dehority, B. A. 1993. Laboratory Manual for Classification and Morphology of Rumen Ciliate Protozoa. CRC Press Inc. Boca Raton, FL.

Dijkstra, J. 1994. Simulation of the dynamics of protozoa in the rumen. Br. J. Nutr. 72:679-699.

Djouvinov, D. S., and N. A. Todorov. 1994. Influence of dry matter intake and passage rate on microbial protein synthesis in the rumen of sheep and its estimation by cannulation and a non-invasive method. Anim. Feed Sci. Technol. 48:289-304.

Dubois, M., K. A. Gilles, J. K. Hamilton, P. A. Rebers, and F. Smith. 1956. Colorimetric method for determination of sugars and related substances. Anal. Chem. (Wash.) 28:350-356.

Environment Canada. 2013. Greenhouse Gas Sources and Sinks in Canada, National Inventory Report 1990-2011. Environment Canada, Ottawa, ON.

FAO. 2006. Livestock's long shadow. Environmental issues and options. Food and Agriculture Organization of the United Nations. Accessed Feb. 13, 2013. http://www.fao.org/docrep/010/a0701e/ a0701e00.htm.

Goad, D. W., C. L. Goad, and T. G. Nagaraja. 1998. Ruminal microbial and fermentative changes associated with experimentally induced subacute acidosis in steers. J. Anim. Sci. 76:234-241.

Gozho, G. N., and T. Mutsvangwa. 2008. Influence of carbohydrate source on ruminal fermentation characteristics, performance, and microbial protein synthesis in dairy cows. J. Dairy Sci. 91:27262735 .

Hall, M. B., J. P. Jennings, B. A. Lewis, and J. B. Robertson. 2001. Evaluation of starch analysis methods for feed samples. J. Sci. Food Agric. 81:17-21.

Hassanat, F., R. Gervais, C. Julien, P. Y. Chouinard, D. I. Massé, A. Lettat, H. V. Petit, and C. Benchaar. 2013. Replacing alfalfa silage with corn silage in dairy cow diets: Effects on enteric methane production, ruminal fermentation, digestion, $\mathrm{N}$ balance, and milk production. J. Dairy Sci. 96:4553-4567.

Hegarty, R. S. 1999. Reducing rumen methane emissions through elimination of rumen protozoa. Aust. J. Agric. Res. 50:1321-1327.

Hristov, A. N., M. Ivan, L. M. Rode, and T. A. McAllister. 2001 Fermentation characteristics and ruminal ciliate protozoal populations in cattle fed medium- or high-concentrate barley-based diets. J. Anim. Sci. 79:515-524.

Hristov, A. N., J. K. Ropp, K. L. Grandeen, S. Abedi, R. P. Etter, A. Melgar, and A. E. Foley. 2005. Effect of carbohydrate source on ammonia utilization in lactating dairy cows. J. Anim. Sci. 83:408-421.

Ivan, M., L. Neill, R. Forster, R. Alimon, L. M. Rode, and T. Entz. 2000. Effects of isotricha, dasytricha, entodinium, and total fauna on ruminal fermentation and duodenal flow in wethers fed different diets. J. Dairy Sci. 83:776-787.

Jenkins, T. C., and M. A. McGuire. 2006. Major advances in nutrition: Impact on milk composition. J. Dairy Sci. 89:1302-1310.

Kebreab, E., K. A. Johnson, S. L. Archibeque, D. Pape, and T. Wirth. 2008. Model for estimating enteric methane emissions from United States dairy and feedlot cattle. J. Anim. Sci. 86:2738-2748.

Keunen, J. E., J. C. Plaizier, L. Kyriazakis, T. F. Duffield, T. M. Widowski, M. I. Lindinger, and B. W. McBride. 2002. Effects of a subacute ruminal acidosis model on the diet selection of dairy cows. J. Dairy Sci. 85:3304-3313.

Khafipour, E., D. O. Krause, and J. C. Plaizier. 2009. Alfalfa pelletinduced subacute ruminal acidosis in dairy cows increases bacterial endotoxin in the rumen without causing inflammation. J. Dairy Sci. 92:1712-1724.

Lettat, A., and C. Benchaar. 2013. Diet-induced alterations in total and metabolically active microbes within the rumen of dairy cows. PLoS ONE 8:e60978.

Martin, C., D. P. Morgavi, and M. Doreau. 2010. Methane mitigation in ruminants: From microbe to the farm scale. Animal 4:351-365.

Mc Geough, E. J., P. O'Kiely, P. A. Foley, K. J. Hart, T. M. Boland, and D. A. Kenny. 2010a. Methane emissions, feed intake, and performance of finishing beef cattle offered maize silages harvested at 4 different stages of maturity. J. Anim. Sci. 88:1479-1491.

Mc Geough, E. J., P. O'Kiely, K. J. Hart, A. P. Moloney, T. M. Boland, and D. A. Kenny. 2010b. Methane emissions, feed intake, performance, digestibility, and rumen fermentation of finishing beef cattle offered whole-crop wheat silages differing in grain content. J. Anim. Sci. 88:2703-2716.

McDonald, I. 1981. A revised model for the estimation of protein degradability in the rumen. J. Agric. Sci. (Camb.) 96:251-252.

Monteils, V., M. Rey, M. Silberberg, L. Cauquil, and S. Combes. 2012. Modification of activities of the ruminal ecosystem and its bacterial and protozoan composition during repeated dietary changes in cows. J. Anim. Sci. 90:4431-4440.

Morgavi, D. P., C. Martin, J.-P. Jouany, and M. J. Ranilla. 2012. Rumen protozoa and methanogenesis: Not a simple cause-effect relationship. Br. J. Nutr. 107:388-397.

NRC. 2001. Nutrient Requirements for Dairy Cattle. Natl. Acad. Press, Washington DC.

Oba, M., and M. S. Allen. 2000a. Effects of brown midrib 3 mutation in corn silage on productivity of dairy cows fed two concentrations of dietary neutral detergent fiber: 1 . Feeding behavior and nutrient utilization. J. Dairy Sci. 83:1333-1341.

Oba, M., and M. S. Allen. 2000b. Effects of brown midrib 3 mutation in corn silage on productivity of dairy cows fed two concentrations of dietary neutral detergent fiber: 3. Digestibility and microbial efficiency. J. Dairy Sci. 83:1350-1358.

Offner, A., A. Bach, and D. Sauvant. 2003. Quantitative review of in situ starch degradation in the rumen. Anim. Feed Sci. Technol. 106:81-93.

Ogimoto, K., and S. Imai. 1981. Techniques of rumen microbiology. Page 158 in Atlas of Rumen Microbiology. Japan Sci. Soc. Press, Tokyo, Japan.

Plaizier, J. C., J. E. Keunen, J. P. Walton, T. F. Duffield, and B. W. McBride. 2001. Effect of subacute ruminal acidosis on in situ 
digestion of mixed hay in lactating dairy cows. Can. J. Anim. Sci. 81:421-423.

Purushe, J., D. E. Fouts, M. Morrison, B. A. White, R. I. Mackie, P. M. Coutinho, B. Henrissat, and K. E. Nelson. 2010. Comparative genome analysis of Prevotella ruminicola and Prevotella bryantii: Insights into their environmental niche. Microb. Ecol. 60:721-729.

Reynolds, C. K., L. A. Crompton, and J. A. N. Mills. 2011. Improving the efficiency of energy utilisation in cattle. Anim. Prod. Sci. 51:6-12.

Russell, J. B., C. J. Sniffen, and P. J. Van Soest. 1983. Effect of carbohydrate limitation on degradation and utilization of casein by mixed rumen bacteria. J. Dairy Sci. 66:763-775.

Taylor, K. 1996. A simple colorimetric assay for muramic acid and lactic acid. Appl. Biochem. Biotechnol. 56:49-58.

Tyrrell, H. F., and J. T. Reid. 1965. Prediction of the energy value of cow's milk. J. Dairy Sci. 48:1215-1223.

Ueda, K., A. Ferlay, J. Chabrot, J. J. Loor, Y. Chilliard, and M. Doreau. 2003. Effect of linseed oil supplementation on ruminal digestion in dairy cows fed diets with different forage:concentrate ratios. J. Dairy Sci. 86:3999-4007.

Van Kessel, J. A. S., and J. B. Russell. 1996. The effect of pH on ruminal methanogenesis. FEMS Microbiol. Ecol. 20:205-210.
Van Soest, P. J. 1994. Nutritional Ecology of the Ruminant. Comstock Pub., Ithaca, NY.

Van Soest, P. J., J. B. Robertson, and B. A. Lewis. 1991. Methods for dietary fiber, neutral detergent fiber, and nonstarch polysaccharides in relation to animal nutrition. J. Dairy Sci. 74:3583-3597.

Weatherburn, M. 1967. Phenol-hypochlorite reaction for determination of ammonia. Anal. Chem. (Wash.) 28:971-974.

Whelan, S. J., K. M. Pierce, C. McCarney, B. Flynn, and F. J. Mulligan. 2012. Effect of supplementary concentrate type on nitrogen partitioning in early lactation dairy cows offered perennial ryegrass-based pasture. J. Dairy Sci. 95:4468-4477.

Wolin, M. J., and T. L. Miller. 1988. Microbe-microbe interactions. Pages 343-359 in The Rumen Microbial Ecosystem. P. N. Hobson, ed. Elsevier Science Pub. Co., New York, NY.

Yahaghi, M., J. B. Liang, J. Balcells, R. Valizadeh, A. R. Alimon, and Y. W. Ho. 2012. Effect of replacing barley with corn or sorghum grain on rumen fermentation characteristics and performance of Iranian Baluchi lamb fed high concentrate rations. Anim. Prod. Sci. $52: 263-268$. 